\title{
Bufalin Inhibits Platelet-Derived Growth Factor-BB-Induced Mesangial Cell Proliferation through Mediating Cell Cycle Progression
}

\author{
Bin Wang, ${ }^{\#}$ Aiqing Zhang, ${ }^{\#}$ Jun Zheng, Jing Gong, Shanwen Li, Zhifeng Zeng, and Weihua Gan* \\ Department of Pediatric Nephrology, the Second Affiliated Hospital of Nanjing Medical University; Nanjing 210011, P. R. \\ China. Received November 10, 2010; accepted February 25, 2011; published online April 21, 2011
}

\begin{abstract}
Bufalin, a traditional Chinese medicine, has been reported as a protective factor in many tumors. We therefore investigated the effect of bufalin on platelet-derived growth factor (PDGF)-BB-induced proliferation of cultured rat mesangial cells. The effect of bufalin on cell proliferation and its underlying mechanisms were investigated in cultured rat mesangial cells (MCs) by the methylthiazoletetrazolium (MTT) assay, flow cytometry, reverse transcription-polymerase chain reaction (RT-PCR), Western blotting, and cyclin-dependent kinases (CDK)2 and CDK4 kinase assays. Bufalin inhibited $20 \mathrm{ng} / \mathrm{ml}$ PDGF-BB-induced MC proliferation in a dosedependent manner. Similar results were observed in different concentrations of bufalin, which blocked PDGFBB-induced progression through G0/G1 to S phase of the cell cycle. Furthermore, bufalin not only inhibited upregulation of cyclin D1 and CDK4, but also downregulation of p21 in both mRNA and protein levels. Although bufalin did not affect p27 and CDK2 mRNA expression, it reversed downregulation of p27 and upregulation of CDK2 in protein level. Activity of CDK2 and CDK4 was also inhibited by bufalin. However, both bufalin and PDGF-BB did not affect cyclin E mRNA or protein expression. These results suggest that bufalin could inhibit MC proliferation by modulating cell cycle progress, indicating that bufalin could be a potential therapeutic agent for the prevention of mesangial proliferative glomerulonephritis.
\end{abstract}

Key words bufalin; mesangial cell; cell cycle; platelet-derived growth factor BB; mesangial proliferative glomerulonephritis

Considerable evidence indicates that proliferation of renal mesangial cells (MCs) is an early event in proliferative glomerulonephritis (GN) and that reduction of MC proliferation is an effective inhibitor of renal disease progression. ${ }^{1)}$ Platelet-derived growth factor-BB (PDGF-BB), which is generally believed a crucial growth factor for MC proliferation, plays an important role in the pathogenesis of mesangial proliferative glomerular disease. Specific antagonism of PDGF reduces MC proliferation and glomerulosclerosis in experimental mesangial proliferative glomerular disease. ${ }^{2-5)}$

Various mitogenic stimuli share the cell cycle as the final common pathway in the proliferative signaling cascade. Modulation of the expression and function of cell cycle regulatory proteins is an important mechanism for cell growth inhibition. ${ }^{6}$ Generally, the cell cycle is a tightly controlled nuclear event regulated positively by cyclin-dependent kinases (CDK) and their specific regulatory cyclin proteins, and negatively by cyclin-dependent kinase inhibitors (CKIs) that confer their effects mainly during the first gap phase $(\mathrm{G} 0 / \mathrm{G} 1)$ of the cell cycle. ${ }^{7,8)}$ The growth of MCs is tightly regulated through a precious balance between the levels and activities of cyclin-CDK complexes and CKIs. ${ }^{9}$ Functional activation of CDK-cyclin is required for cell cycle progression, ${ }^{10,11)}$ and some studies have identified a role for CKIs p21 and p27 in proliferation of rat MC. ${ }^{12-15)}$

Various drugs, including cyclophosphamide (CTX) and cyclosporine A (CsA), which are efficacious against cancers, have been applied for the treatment of mesangial proliferative diseases such as mesangial proliferative glomerulonephritis (MsPGN) and immunoglobulin A (IgA) nephropathy. ${ }^{16-18)}$ However, high recurrence rates after medical treatments are the most significant problem. ${ }^{19)}$ In addition, current treatments for these diseases can be used only for a limited time owing to unacceptable side effects. Therefore novel therapeutic strategies are necessary for the improved clinical management of patients.
Bufalin, the chemical structure of which is shown in Fig. 1 , is a major component of Chan $\mathrm{Su}$, a traditional Chinese medicine, obtained from the skin and parotid venom glands of toads ${ }^{20)}$ Bufalin, a cardiotonic steroid, exhibits a variety of pharmaceutical activities such as cardiotonic, anesthetic, blood pressure stimulation, respiration and antineoplastic activities. ${ }^{21,22)}$ In terms of its antitumor activities, bufalin has been demonstrated to inhibit the growth of tumor cells such as hepatoma and gastric cancer. ${ }^{23-25)}$

Although the antitumor activities of bufalin have been analyzed in several tumors, no information is available on the effect of bufalin on the proliferation of rat MC induced by PDGF-BB. Thus the aim of this study was to investigate whether bufalin could inhibit PDGF-BB stimulated cell proliferation and the possible underlying mechanisms in a rat MC line.

\section{MATERIALS AND METHODS}

Materials The established rat mesangial cell line (MC) HBZY-1 was obtained from The Chinese Center for Type Culture Collection (Wuhan, China). Bufalin and PDGF-BB were from Sigma Chemical Co. (St. Louis, MO, U.S.A.). Cell culture materials were purchased from Gibco BRL (Gaithers-

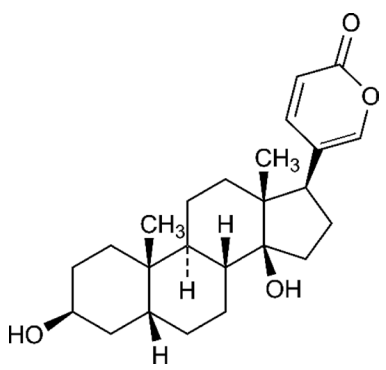

Fig. 1. Chemical Structure of Bufalin 
burg, MD, U.S.A.). $\beta$-Actin, p27, cyclin D1, cyclin E, and CDK2 antibodies were purchased from Cell Signaling Technology, Inc. (Beverly, MA, U.S.A.). CDK4 and p21 antibodies were from milipore (Billerica, MA, U.S.A.). CDK4/Cyclin D1 and CDK2/CYCLIN E Kinase Activity Assay Kit were purchased from Genmed Scientifics Inc. (Arlinghton, MA, U.S.A.). All other chemicals were of analytical grade.

Cell Culture The cells were cultured in Dulbecco's modified Eagle's medium (DMEM) supplemented with 10\% fetal calf serum, $2 \mathrm{~mm}$ glutamine, $100 \mathrm{U} / \mathrm{ml}$ penicillin, and $100 \mu \mathrm{g} / \mathrm{ml}$ streptomycin at $37^{\circ} \mathrm{C}$ in an atmosphere containing $5 \% \mathrm{CO}_{2}$. GMC cells between passages 3 and 10 were used for experiments. After preincubation in serum free DMEM for $24 \mathrm{~h}$, cells were then treated with $20 \mathrm{ng} / \mathrm{ml}$ PDGF-BB for $12 \mathrm{~h}$ in DMEM containing 10\% fetal calf serum then different concentrations of bufalin $(0.01,0.04,0.08,0.16 \mu \mathrm{M})$ were added into the DMEM for another 12,24 , and $36 \mathrm{~h}$, respectively.

Cell Proliferation Assay MTT reduction assay was used as qualitative index of cell viability. After 12,24 , and $36 \mathrm{~h}$ incubation with different compounds as described above, $20 \mu \mathrm{l}$ MTT ( $5 \mathrm{mg} / \mathrm{ml}$, Invitrogen Corp., Carlsbad, CA, U.S.A.) was added and cells were cultured for additional $4 \mathrm{~h}$. Subsequently, cells were lysed using dimethylsulfoxide (150 $\mu \mathrm{l} /$ well). When the formanzan crystals were completely dissolved, the optical density (OD) was measured at $490 \mathrm{~nm}$ by Microplate Reader Model 3550-UV Spectrophotometer (BioRad Laboratories, Marnes La Coquette, France).

LDH Toxicity Assay Cytotoxicity was estimated by measuring lactate dehydrogenase (LDH) release into culture medium. Cultured cells were treated with or without $0.16 \mu \mathrm{M}$ bufalin for $24 \mathrm{~h}$ and LDH activity was assayed by absorbance change at a wavelength of $440 \mathrm{~nm}$ with by assay kit (Nanjing Jiancheng Bioengineering Institute, Nanjing, China).

Flow Cytometry Cell cycle analysis was performed using flow cytometry. After $24 \mathrm{~h}$ treatment with different compounds, cells were harvested and fixed in $70 \%$ ethanol and stored at $-20^{\circ} \mathrm{C}$. They were then washed twice with phosphate-buffered saline (PBS), harvested by trypsinization, centrifuged, and suspended with $1 \mathrm{ml}$ cold PBS and then fixed in methanol on ice for $30 \mathrm{~min}$. Following two washes with PBS, fixed cells were incubated in RNase $(25 \mu \mathrm{g} / \mathrm{ml})$ at $37^{\circ} \mathrm{C}$ for $30 \mathrm{~min}$, followed by staining of the DNA with propidium iodide $(50 \mu \mathrm{g} / \mathrm{ml})$ at $4{ }^{\circ} \mathrm{C}$ for $30 \mathrm{~min}$ in the dark. Then, each sample was analyzed using a Coulter Epics XL Flow Cytometer (Miami, FL, U.S.A.) and the proportion (percentage) of cells within the G1, S, and G2/M phases of the cell cycle was determined.

Reverse Transcription-Polymerase Chain Reaction (RT-PCR) To evaluate the expression level of p21, p27, cyclin D1, cyclin E, CDK2, and CDK4 mRNA, we performed a semiquantitative RT-PCR. The efficiency of the RT-PCR was controlled by glyceraldehyde-3-phosphate dehydrogenase (GAPDH) amplification. Each sample mixture contained standard PCR buffer, $2.5 \mathrm{~mm}$ dNTP, $2 \mathrm{U}$ Taq polymerase, and $5 \mathrm{pm}$ of each of the following primers: GAPDH, 5'CAAGTTCAACGGCACAGTCAA-3' and 5'-TGGTGAAGACGCCAGTAGACTC-3'; p21, 5'-GTATGCCGTCGTCTGTTCGG-3' and 5'-GCAGAAGACCAATCGGCGCT-3'; p27, 5'-AACCTCTTCGGCCCGGTCAATC-3' and 5'-TGCTCCACAGTGCCAGCATTCG-3'; cyclin D1, 5'-TGGAGC-

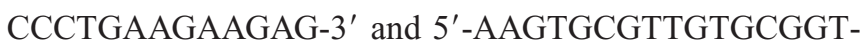
AGC-3'; cyclin E, 5'-CTGGCTGAATGTTTATGTCC-3' and 5'-TCTTTGCTTGGGCTTTGTCC-3', CDK2, 5'-AAGATCGGAGAGGGCACGTACGGAGTGGTG-3' and 5'-AGGCTCTTGCTAGTCCAAAGTCTGCCAACT-3'; CDK4, 5'-GCTACCACTCGATATGAACCCGTGGCTGAA-3' and $5^{\prime}$-GGTGCTTTGTCCAGGTATGTCCGTAGGTCC- $3^{\prime}$. The PCR cycles consisted of steps at $95^{\circ} \mathrm{C}$ for $5 \mathrm{~min}$, a denaturation step at $94{ }^{\circ} \mathrm{C}$ for $30 \mathrm{~s}$, an annealing step at $51.9^{\circ} \mathrm{C}$ (cyclin $\mathrm{D} 1$, cyclin E, p21, and p27), at $57.9^{\circ} \mathrm{C}(\mathrm{CDK} 2$ and CDK4), and an extension step at $72^{\circ} \mathrm{C}$ for $30 \mathrm{~s}$, then 32 cycles (for p21, p27, cyclin D1, cyclin E, CDK2, CDK4), 28 cycles (for GAPDH) and a final extension at $72{ }^{\circ} \mathrm{C}$ for $7 \mathrm{~min}$. The expected PCR product size was 149 bp (for GAPDH), $415 \mathrm{bp}$ (for p21), $467 \mathrm{bp}$ (for p27), $424 \mathrm{bp}$ (for cyclin D1), $386 \mathrm{bp}$ (for cyclin E), $320 \mathrm{bp}$ (for CDK4), and $430 \mathrm{bp}$ (for CDK2). The reaction products were subjected to computer-assisted densitometry after electrophoresis on a $2 \%$ agarose gel and staining with ethidium bromide.

Western Blotting After being treated with different compounds for $24 \mathrm{~h}$, cells were harvested and washed with ice-cold phosphate buffer. Total cellular proteins were extracted by lysing cells with buffer containing $150 \mathrm{~mm} \mathrm{NaCl}$, $0.1 \%$ Triton X-100, $0.5 \%$ Deoxycholate, $0.1 \%$ sodium dodecyl sulfate (SDS), $50 \mathrm{~mm}$ Tris-HCl (pH 7.0), and $1 \mathrm{~mm}$ ethylenediaminetetraacetic acid (EDTA), and nuclear proteins were obtained using methods described previously. ${ }^{26)}$ Protein concentrations were determined by BCA method (Beyotime Institute of Biotechnology, China). Eighty micograms of MC protein extract was loaded onto each lane, separated by SDSpolyacrylamide gel electrophoresis (PAGE), and transferred to nitrocellulose membranes. After being blocked with 5\% skimmed milk in Tris-buffered saline (TBS) $(\mathrm{pH}$ 7.6) at room temperature, the membranes were incubated at $4{ }^{\circ} \mathrm{C}$ overnight with primary antibodies for p21 (1:5000), p27 $(1: 1000)$, cyclin D1 $(1: 1000)$, cyclin E $(1: 1000)$, CDK2 ( $1: 1000)$, CDK4 $(1 \mu \mathrm{g} / \mathrm{ml})$, and $\beta$-actin $(1: 500)$. After being incubated with the respective second antibody, immune complexes were detected by ECL Western blotting reagents. The detected proteins were normalized to $\beta$-actin or the respective total protein as appropriate.

CDK4 and CDK2 Kinase Activity Assays The CDK4/ cyclin D1 and CDK2/cyclin E kinase activity assay kit is a complete assay system designed to measure the activity of CDK4/cyclin D1 and CDK2/cyclin E by coupling the formation of ADP to the reaction catalyzed by PK and LDH in the presence of phosphoenolpyruvate (PEP) with oxidation of NADH. The disappearance of NADH is detected by measuring a decrease in extinction at $340 \mathrm{~nm}$. Samples were assayed according to the manufacturer's instructions.

Statistical Analysis Statistical differences were tested by analysis of variance (ANOVA). All values are expressed as mean \pm S.D. and statistical significance was defined as $p<0.05$.

\section{RESULTS}

Effect of Bufalin on Cell Proliferation Induced by PDGF-BB in Rat MCs MC proliferation was evaluated by MTT analysis. Compared with the control group, $20 \mathrm{ng} / \mathrm{ml}$ PDGF-BB increased MC proliferation after treatment for 
$24 \mathrm{~h}(p<0.05)$. However, addition of bufalin inhibited PDGF-induced MC proliferation in a dose-dependent manner at concentrations ranging from 0.01 to $0.16 \mu \mathrm{M}$ (Fig. 2). In addition, $0.16 \mu \mathrm{m}$ bufalin had no effect on $\mathrm{MC}$ growth

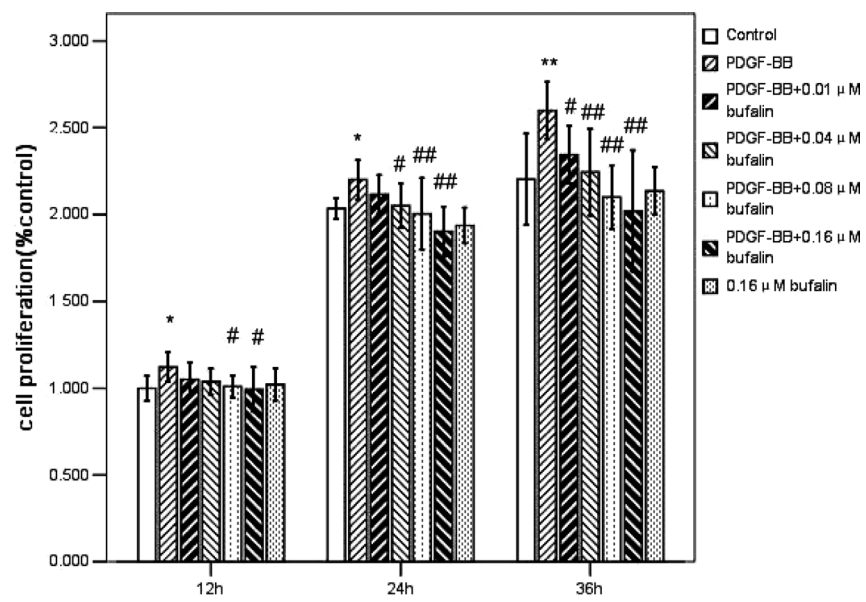

Fig. 2. Effect of Bufalin on MC Proliferation Stimulated by PDGF-BB Using the MTT Assay

Bufalin inhibited MC proliferation induced by PDGF-BB at final concentrations $0.01,0.04,0.08$, and $0.16 \mu \mathrm{M}$, respectively, in culture media. MC were treated with $20 \mathrm{ng} / \mathrm{ml}$ PDGF-BB for $12 \mathrm{~h}$, then different concentrations of bufalin $(0.01,0.04,0.08$, $0.16 \mu \mathrm{M})$ were added into the DMEM for another 12,24 , and $36 \mathrm{~h}$ respectively. Values are given as mean \pm S.D. from three independent experiments and $p<0.05$ is considere statistically significant. $* p<0.05 v s$. control, $* * p<0.01 v s$. stimulus control, $\# p<0.05$ vs. control, \#p<0.01 vs. stimulus control. $(p>0.05)$.

Twenty-four-hour treatment with $0.16 \mu \mathrm{M}$ bufalin did not affect LDH concentration in the supernatant (control, $0.533 \pm 0.114$ versus $0.16 \mu \mathrm{m}$ bufalin, $0.564 \pm 0.145, p>$ 0.05 ); moreover, detached cells in supernatant were $<5 \%$ and did not differ from the control group, suggesting that the antiproliferative effect of bufalin upon cultured MC was not due to bufalin's cytotoxicity. Therefore $0.16 \mu \mathrm{M}$ bufalin was used in all subsequent studies since it achieved the desired inhibition without any obvious toxicity.

Effect of Bufalin on Cell Cycle Distribution Induced by PDGF-BB in Rat MCs Further to evaluate the effect of bufalin treatment on cell cycle profiles, we next performed flow cytometry. Figure 3 shows that PDGF treatment decreased the proportion of cells in G1 (from 83.98 \pm 1.06 to $72.85 \pm 2.36 \% ; p<0.01$ ) and increased that in $\mathrm{S}$ phase (from $8.68 \pm 1.31$ to $18.63 \pm 0.47 \% ; p<0.01$ ), indicating that PDGF could promote cell cycle progression. In contrast, addition of bufalin increased the number of cells in G1 to $75.08 \pm 2.23 \%$ $(p>0.05 ; n=3), 82.06 \pm 1.22 \% \quad(p<0.01 ; n=3), 82.83 \pm$ $1.23 \%(p<0.01 ; n=3)$, and $85.14 \pm 1.05 \%(p<0.01 ; n=3)$ and decreased that in $\mathrm{S}$ phase to $16.96 \pm 1.39 \%(p>0.05$; $n=3), 11.87 \pm 0.85 \%(p>0.05 ; n=3), 9.95 \pm 0.79 \%(p>0.05$; $n=3)$, and $8.58 \pm 1.32 \%(p>0.05 ; n=3)$ at $0.01,0.04,0.08$ and $0.16 \mu \mathrm{M}$, respectively. These results show that bufalin could block PDGF-BB-induced cell cycle progression by inhibiting G1-S phase transition and arresting cells in G1.
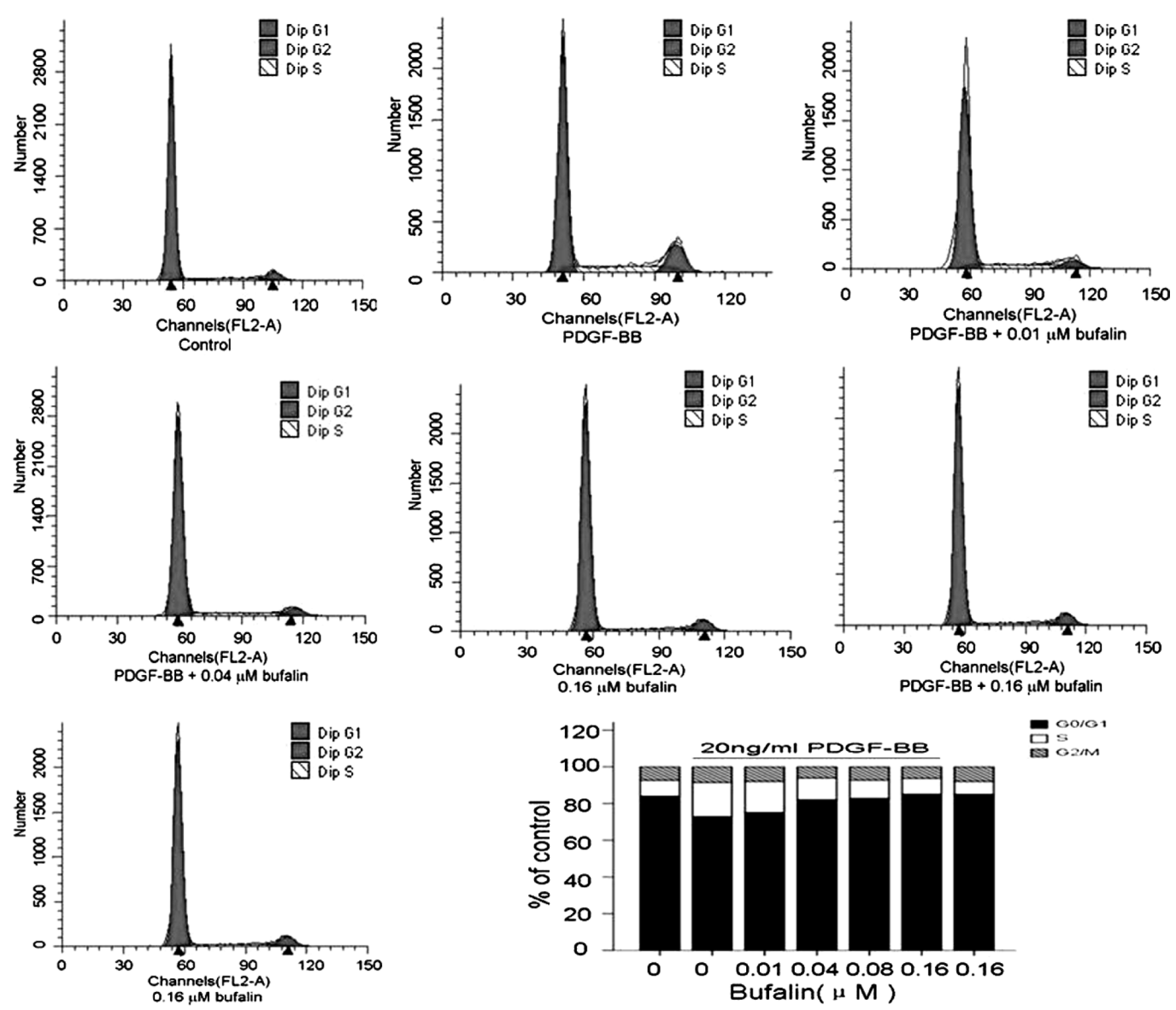

Fig. 3. Effect of Bufalin on PDGF-BB-Induced Cell Cycle Progression in MCs

Quiescent MC were stimulated with PDGF-BB $(20 \mathrm{ng} / \mathrm{ml})$ for $12 \mathrm{~h}$ then exposed to differernt concentrations $(0.01-0.16 \mu \mathrm{M})$ of bufalin for $24 \mathrm{~h}$. Data are expressed as percentage of total cells. Each item is derived from a representative experiment where data from $>10000$ events were obtained. Values are given as mean \pm S.D. from three independent experiments and $p<0.05$ is considered statistically significant. 


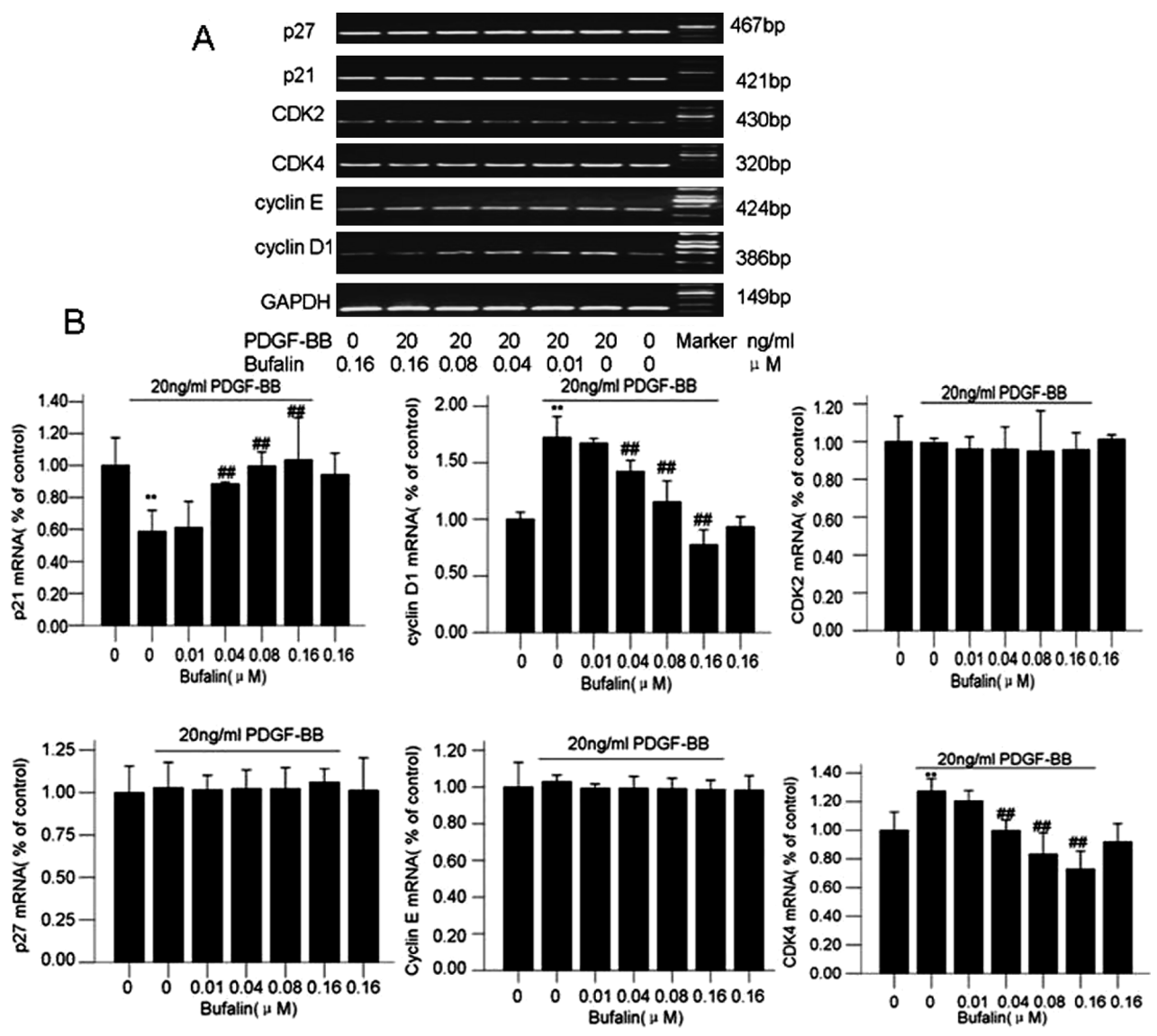

Fig. 4. Effect of PDGF-BB and Different Concentrations of Bufalin on Cell Cycle-Related Gene Expression in Cultured MCs

(A) Quiescent MC were stimulated with PDGF-BB $(20 \mathrm{ng} / \mathrm{ml})$ for $12 \mathrm{~h}$ then exposed to differernt concentrations $(0.01-0.16 \mu \mathrm{M})$ of bufalin for $24 \mathrm{~h}$. Total RNA was extracted at the indicated time from cultured MC and analyzed by RT-PCR as described in Materials and Methods for cyclin D1, cyclin E, CDK2, CDK4, p21, p27, and GAPDH. "PDGF-BB $0 \mathrm{ng} / \mathrm{ml}$ " refers to cells growing in DMEM containing 10\% FCS, without PDGF-BB intervention. (B) Quantitative analyses were performed for cyclin D1, cyclin E, CDK2, CDK4, p21, and 27 by densitometer. Each bar represents mean \pm S.D. $(n=3 ; * * p<0.01 v$ s. control; \#p<0.01 vs. stimulus control).

Effect of Bufalin on mRNA Expression of Cyclin D1, Cyclin E, CDK4, CDK2, p21, and p27 Induced by PDGFBB in Rat MCs To determine the possible action mechanism of bufalin on MC proliferation, we evaluated expression of cyclin D1, cyclin E, CDK4, CDK2, p21, and p27 genes by semi-quantitative RT-PCR. Taking the mRNA level in the control as 1, cyclin D1 and CDK4 mRNA levels were significantly increased by $20 \mathrm{ng} / \mathrm{ml}$ PDGF-BB to the following levels: cyclin D1, 1.724 \pm 0.075 ; CDK4, 1.274 \pm 0.035 ; however, PDGF-BB strongly inhibited p21 mRNA expression to $0.587 \pm 0.054$ (Fig. 4). Bufalin could inhibit PDGFBB-induced upregulation of cyclin D1 and CDK4 and downregulation of p21 mRNA level in a dose-dependment manner from 0.04 to $0.16 \mu \mathrm{M}(p<0.01)$. However, $0.16 \mu \mathrm{M}$ bufalin displayed no significant change on normal $\mathrm{MC}(p>0.05)$. In addition, both PDGF-BB and bufalin did not affect cyclin E, CDK2, and p27 mRNA expression ( $p>0.05)$.

Effect of Bufalin on Protein Expression of Cyclin D1, Cyclin E, CDK4, CDK2, p21, and p27 Induced by PDGFBB in Rat MCs Cell cycle progression is tightly regulated through a complex network of positive and negative cell cycle regulatory molecules such as CDKs, cyclins, and CKIs. To clarify whether inhibition by bufalin involves regulation of cell cycle-related proteins, we assessed G1-checkpoint proteins in bufalin-treated cell cycle arrest. As shown in Fig. 5 , bufalin significantly decreased the level of CDK2, CDK4, and cyclin D1 induced by PDGF-BB in a dose-dependent manner, but did not change that of cyclin E. In addition, p27 and $\mathrm{p} 21$ protein levels were rapidly downregulated by PDGF$\mathrm{BB}$, whereas those of $\mathrm{p} 27$ and $\mathrm{p} 21$ protein were significantly increased by bufalin treatment in a concentration-dependent manner $(p<0.01)$. Bufalin alone did not show any effect on CDK2, CDK4, cyclin D1, p27, and p21 expression $(p>0.05)$. Furthermore, both PDGF-BB and bufalin did not affect cyclin $\mathrm{E}$ expression $(p>0.05)$. These results indicate that bufalin regulates the activity of $\mathrm{G} 1$ and $\mathrm{S}$ phase-related G1-checkpoint proteins in association with its cell cycle arrest effects in MCs.

Effect of Bufalin on Activity of CDK4 and CDK2 Induced by PDGF-BB in Rat MCs We also examined bufalin's effects on CDK4 and CDK2 activation, which governs G1/S progression of the cell cycle. As shown in Fig. 6, 36 h of PDGF-BB treatment increased CDK4 and CDK2 kinase activities to 1.35 times and 1.57 times control levels, respectively. These stimulatory effects of PDGF-BB on CDK4 and CDK2 were significantly inhibited by bufalin from 0.04 to $0.16 \mu \mathrm{M}$. These data suggest that the effect of bufalin in inhibiting CDK4 and CDK2 activities that are responsible for the downregulation of the G1/S transition may play roles in the PDGF-BB-induced stimulation of MC proliferation. 


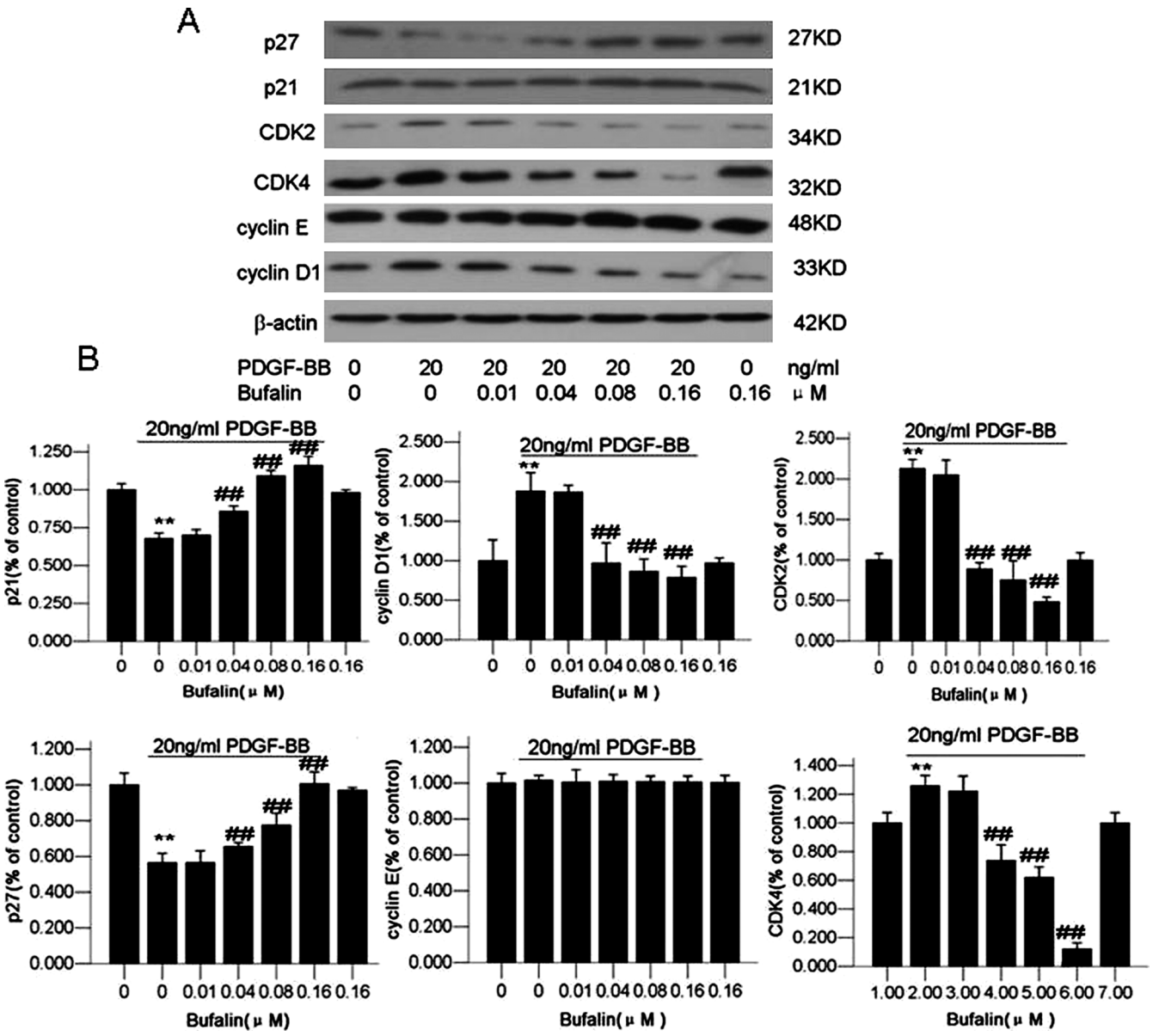

Fig. 5. The Effect of PDGF-BB and Different Concentrations of Bufalin on Cyclin D1, Cyclin E, CDK2, CDK4, p21, and p27 Levels in Rat MCs

(A) Quiescent MC were stimulated with PDGF-BB $(20 \mathrm{ng} / \mathrm{ml})$ for $12 \mathrm{~h}$ then exposed to differernt concentrations $(0.01-0.16 \mu \mathrm{M})$ of bufalin for $24 \mathrm{~h}$. Total cellular protein was extracted at indicated time. Twenty micrograms of protein was loaded for Western blot analysis for cyclin D1, cyclin E, CDK2, CDK4, p21, and p27. Similar results were obtained from repeated experiments. "PDGF-BB $0 \mathrm{ng} / \mathrm{ml}$ " refers to cells growing in DMEM containing $10 \% \mathrm{FCS}$, without PDGF-BB intervention. (B) Quantitative analyses were performed for cyclin D1, cyclin E, CDK2, CDK4, p21, and p27 by densitometer. Each bar represents mean \pm S.D. $(n=3 ; * * p<0.01 v s$. control; \#p $p<0.01$ vs. stimulus control).
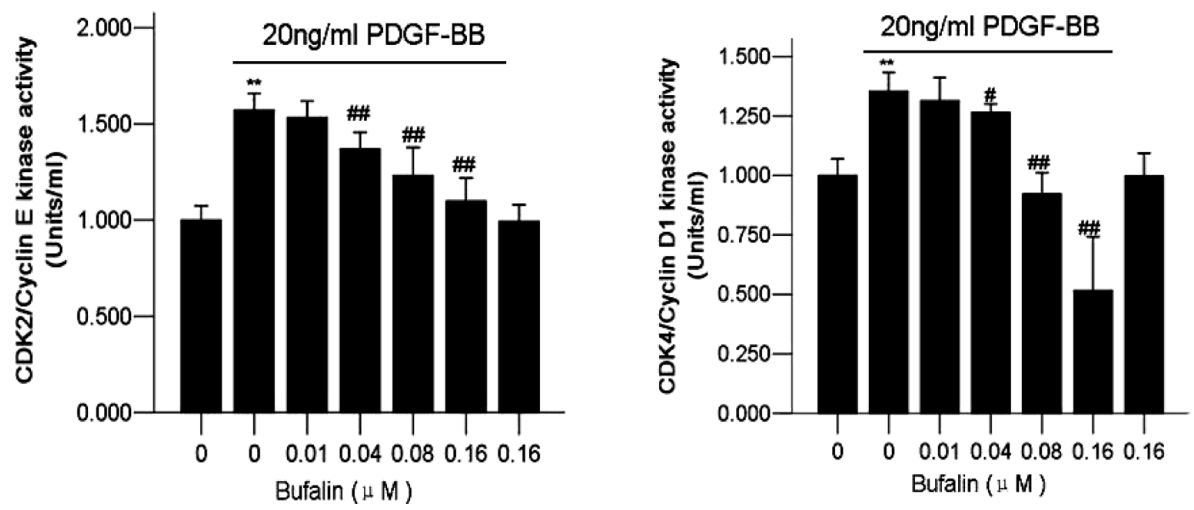

Fig. 6. Effect of PDGF-BB and Different Concentrations of Bufalin on CDK2 and CDK4 Activities in Cultured Rat MCs

Cells were pretreated with an FCS $(-)$ medium for $24 \mathrm{~h}$. Quiescent MC were stimulated with PDGF-BB $(20 \mathrm{ng} / \mathrm{ml})$ for $12 \mathrm{~h}$ then exposed to differernt concentrations $(0.01-$ $0.16 \mu \mathrm{M}$ ) of bufalin for $24 \mathrm{~h}$, and total cellular protein was extracted at indicated time. Then, kinase assay was performed as described in Materials and Methods. "PDGF-BB $0 \mathrm{ng} / \mathrm{ml}$ " refers to cells growing in DMEM containing $10 \%$ FCS, without PDGF-BB intervention. Each bar represents the mean \pm S.D. $(n=3 ; * * p<0.01 v s$. control; $\# p<0.05 v s$. stimulus control; \#p<0.01 vs. stimulus control).

\section{DISCUSSION}

In our recent study, we showed inhibitory effect of bufalin on PDGF-BB-induced MCs proliferation. To elucidate the underlying mechanism, we demonstrated that bufalin arrests the cell-cycle transition from G1 to S phase. Upregulation of p21 and downregulation of cyclin D1 and CDK4 in both
mRNA and protein levels were responsible for this cell cycle arrest. Although CDK2 and p27 mRNA levels were not significantly changed by either PDGF-BB or bufalin, p27 protein level was increased whereas CDK2 protein level was decreased in PDGF-BB-induced MCs. Additionally, the inhibitory effect of bufalin on CDK4 and CDK2 activity was shown to participate in $\mathrm{MC}$ proliferation stimulated 
by PDGF-BB exposure.

After glomerular injury, a number of cytokines including interleukin-1 (IL-1), tumor necrosis factor alpha (TNF $\alpha$ ), and PDGF may serve to sustain the inflammatory process, thereby promoting ongoing $\mathrm{MC}$ proliferation and extracellular matrix production leading to progressive glomerular damage. In this study, PDGF-BB induced rat MCs were used as an in vitro model that has been widely studied in both human and experimental mesangial proliferative renal disease. A number of in vitro and in vivo studies on bufalin have revealed that its beneficial effects on proliferative diseases may be due to modulation of abnormal cell proliferation.

Thus it is interesting to investigate the effect induced by bufalin on PDGF-BB-induced MC. In the proliferation assay, we clearly demonstrated that bufalin potently inhibited PDGF-BB-induced proliferation of MC (Fig. 2). However, the antiproliferative effect of bufalin was not due to cytotoxicity or apoptosis, as demonstrateded by LDH.

Further to investigate the antiproliferative effect of bufalin, flow cytometry analysis was performed. As revealed by flow cytometry assays, the antiproliferative effect of bufalin was associated with an accumulation of cells in G0/G1 phase of the cell cycle (Fig. 3). This result strongly indicates that bufalin targets signal transduction event(s) in the G0/G1-S interphase rather than those involved in the $\mathrm{S}$ or $\mathrm{G} 2 / \mathrm{M}$ phase.

Cell cycle control is a highly regulated process that involves a complex cascade of events. Modulation of expression and function of cell cycle regulatory proteins (including CDKs, cyclins, and CKIs) provides an important mechanism for growth inhibition. ${ }^{27-29)}$ PDGF, indeed, has been well demonstrsted through regulating G1 CDK activity by promoting the synthesis of cyclin subunits, as well as decreasing the levels of CDK inhibitors, thereby stimulating cell proliferation. ${ }^{15,30,31)}$ The finding that bufalin permitted PDGF-induced MC arrest in G0/G1 phase suggests that modulations of several cell cycle regulatory proteins may occur after bufalin treatment. CDK2 and CDK4 are key mediators during the $\mathrm{G} 0 / \mathrm{G} 1$ to $\mathrm{S}$ phase progression of the cell cycle and form complexes with cyclin E and cyclin D1. ${ }^{26,32,33)}$ These complexes mediate phosphorylation of the $\mathrm{C}$-terminal region of retinoblastoma protein leading to active transcriptional repression of E2F complex that promotes DNA synthesis. ${ }^{34,35)}$ In this study, we present the first demonstration that bufalin blocked PDGF-induced MCs proliferation, thereby inhibiting cyclin D1 and CDK4 expression which supporting the results shown in RT-PCR, whereas CDK2 only changed in protein level. This suggests that downregulation of cyclin D1 and CDK4 following bufalin addition may result from enhanced cyclin D1 and CDK4 synthesis, whereas CDK2 may result from decreased rate of degradation and prolonged half-life. Both PDGF-BB and bufalin had no effect on cyclin E expression, indicating that cyclin $\mathrm{E}$ may not participate in bufalin-induced inhibition of cell cycle progression arrest. In addition, the increased activity of CDK2 and CDK4 induced by PDGF-BB was inhibited by bufalin. This suggests that inhibition of activation CDK2 and CDK4 by bufalin abrogated the effect of PDGF-BB in stimulating MC proliferation (Fig. $6)$.

CDK inhibitors such as p21 and p27 are important regulators of cyclin-CDK complexes. They can tightly bind and inhibit the kinase activities of cyclin D1-CDK4 and cyclin E-
CDK2 complexes, and arrest cell growth at the G0/G1 and G1/S boundary. ${ }^{36-39)}$ In accordance with the above finding, bufalin prevented downregulation of p21 and p27 after PDGF-BB stimulation in a concentration-dependent manner (Fig. 5). The alternative expression of $\mathrm{p} 21$ and $\mathrm{p} 27$ protein induced by PDGF-BB/or bufalin could result from $\mathrm{p} 21$ and p27 synthesis, however, decreased levels of p27 protein after bufalin addition in PDGF-BB-induced MC made this alternative less likely. Indeed, we did not find any change of p27 mRNA levels. It has been reported that some drugs that upregulate p21 and p27 expression exhibit potent antiproliferative activity against MCs. ${ }^{40-42)}$ Thus our findings suggest that bufalin upregulation of p21 and p27 expression is consistent with its greater inhibitory effects on expression and activation of multiple cell cycle proteins. CKIs could inhibit CDK activity through combination with the cyclin/CDK complex, leading to changes in the spatial location of active site of CDK molecules. Therefor bufalin-induced inhibition of G1-CDK activities maybe mediated by release and/or redistribution of $\mathrm{p} 21 / \mathrm{p} 27$ proteins to inhibit $\mathrm{CycE} / \mathrm{A}-\mathrm{CDK} 2$ complexes; and changes of the expression of regulatory proteins (CDK2, p27) that modulate CDK2 activity.

In conclusion, our findings may partly explain the mechanism by which bufalin attenuates experimental mesangial proliferative renal disease. Our studies suggest that bufalin may prove useful as a therapeutic approach to mesangial proliferative disease. Furthermore, bufalin caused indiscernible cytotoxicity and has shown few adverse effects in clinical application, indicating that bufalin is a potent and safe drug for MsPGN treatment.

Although it is often difficult and sometimes wrong to extend in vitro results to in vivo conditions, our results are consistent with the above mentioned studies in support of the close link between bufalin and PDGF-BB-induced MC proliferation. Further investigation is needed to determine whether the actions of bufalin in the kidney involve other cell types and receptors. More studies are necessary to develop our understanding of the pathophysiologic actions of bufalin in MCs and glomeruli.

Acknowledgments We thank Dr. Zhirui Guo for technical assistance and helpful discussions. This work was sponsored by the Distinguished Researcher Program of Jiangsu Province of China.

\section{REFERENCES}

1) Johnson R. J., Kidney Int., 45, 1769-1782 (1994).

2) Gilbert R. E., Kelly D. J., McKay T., Chadban S., Hill P. A., Cooper M. E., Atkins R. C., Nikolic-Paterson D. J., Kidney Int., 59, 1324-1332 (2001).

3) Johnson R. J., Raines E. W., Floege J., Yoshimura A., Pritzl P., Alpers C., Ross R., J. Exp. Med., 175, 1413-1416 (1992).

4) Floege J., Ostendorf T., Janssen U., Burg M., Radeke H. H., Vargeese C., Gill S. C., Green L. S., Janjic N., Am. J. Pathol., 154, 169-179 (1999).

5) Ostendorf T., Kunter U., Gröne H. J., Bahlmann F., Kawachi H., Shimizu F., Koch K. M., Janjic N., Floege J., J. Am. Soc. Nephrol., 12, 909-918 (2001).

6) Dzau V. J., Braun-Dullaeus R. C., Sedding D. G., Nat. Med., 8, 1249 1256 (2002).

7) Hunter T., Pines J., Cell, 79, 573-582 (1994).

8) Sherr C. J., Cell, 73, 1059-1065 (1993).

9) Igata M., Motoshima H., Tsuruzoe K., Kojima K., Matsumura T., 
Kondo T., Taguchi T., Nakamaru K., Yano M., Kukidome D., Matsumoto K., Toyonaga T., Asano T., Nishikawa T., Araki E., Circ. Res., 97, 837-844 (2005).

10) Monkawa T., Pippin J., Yo Y., Kopp J. B., Alpers C. E., Shankland S. J., Nephron, Exp. Nephrol., 102, e8-e18 (2006).

11) Cuzzocrea S., Genovese T., Failla M., Vecchio G., Fruciano M., Mazzon E., Di Paola R., Muià C., La Rosa C., Crimi N., Rizzarelli E., Vancheri C., Am. J. Physiol. Lung Cell. Mol. Physiol., 292, L1095L1104 (2007).

12) Terada Y., Yamada T., Nakashima O., Tamamori M., Ito H., Sasaki S., Marumo F., J. Am. Soc. Nephrol., 8, 51-60 (1997).

13) Wolf G., Schroeder R., Zahner G., Stahl R. A., Shankland S. J., Am. J. Pathol., 158, 1091-1100 (2001).

14) Terada Y., Inoshita S., Nakashima O., Yamada T., Kuwahara M., Sasaki S., Marumo F., J. Am. Soc. Nephrol., 9, 2235-2243 (1998).

15) Lin S. L., Chen R. H., Chen Y. M., Chiang W. C., Tsai T. J., Hsieh B. S., Mol. Pharmacol., 64, 811-822 (2003).

16) Chen S. Y., Wu C. Y., Tsai I. J., Tsau Y. K., Nephrology (Carlton), 15, $336-339$ (2010).

17) Lv J., Zhang H., Cui Z., Su T., Zhang Y., Wang H., Nephrol. Dial. Transplant., 23, 2868-2872 (2008).

18) Lim B. J., Kim J. H., Hong S. W., Jeong H. J., Pediatr. Nephrol., 24, $513-519$ (2009).

19) Kuhn A., Ruland V., Bonsmann G, J. Am. Acad. Dermatol., in press, doi: 10.1016/j.jad.2010.06.018 (2010).

20) Krenn L., Kopp B., Phytochemistry, 48, 1-29 (1998).

21) Bagrov A. Y., Roukoyatkina N. I., Fedorova O. V., Pinaev A. G., Ukhanova M. V., Eur. J. Pharmacol., 234, 165-172 (1993).

22) Hauck C. R., Lorenzen D., Saas J., Meyer T. F., Infect. Immun., 65, 1863-1869 (1997).

23) Meng Z., Yang P., Shen Y., Bei W., Zhang Y., Ge Y., Newman R. A., Cohen L., Liu L., Thornton B., Chang D. Z., Liao Z., Kurzrock R., Cancer, 115, 5309-5318 (2009).

24) Li D., Qu X., Hou K., Zhang Y., Dong Q., Teng Y., Zhang J., Liu Y.,
Anticancer Drugs, 20, 59-64 (2009).

25) Yu C. H., Kan S. F., Pu H. F., Jea Chien E., Wang P. S., Cancer Sci., 99, 2467-2476 (2008).

26) Martin A., Odajima J., Hunt S. L., Dubus P., Ortega S., Malumbres M., Barbacid M., Cancer Cell, 7, 591-598 (2005).

27) Braun-Dullaeus R. C., Mann M. J., Sedding D. G., Sherwood S. W., von der Leyen H. E., Dzau V. J., Arterioscler. Thromb. Vasc. Biol., 24, $845-850$ (2004).

28) Sherr C. J., Roberts J. M., Genes Dev., 13, 1501-1512 (1999).

29) Sherr C. J., Cancer Res., 60, 3689-3695 (2000).

30) Mitchell D., Rodgers K., Hanly J., McMahon B., Brady H. R., Martin F., Godson C., Am. J. Pathol., 164, 937-946 (2004).

31) Zahner G., Wolf G., Schroeder S., Stahl R. A., FEBS Lett., 580, 2523-2528 (2006).

32) Sherr C. J., Roberts J. M., Genes Dev., 13, 1501-1512 (1999).

33) Jirawatnotai S., Aziyu A., Osmundson E. C., Moons D. S., Zou X., Kineman R. D., Kiyokawa H., J. Biol. Chem., 279, 51100-51106 (2004).

34) Dzau V. J., Braun-Dullaeus R. C., Sedding D. G., Nat. Med., 8, 12491256 (2002).

35) Sherr C. J., Science, 274, 1672-1677 (1996).

36) Sherr C. J., Cancer Res., 60, 3689-3695 (2000).

37) Akiyama T., Ohuchi T., Sumida S., Matsumoto K., Toyoshima K. Proc. Natl. Acad. Sci. U.S.A., 89, $7900-7904$ (1992).

38) Ortega S., Malumbres M., Barbacid M., Biochim. Biophys. Acta, 1602, $73-87$ (2002).

39) Coqueret O., Trends Cell Biol., 13, 65-70 (2003).

40) Marra D. E., Simoncini T., Liao J. K., Circulation, 102, 2124-2130 (2000).

41) Tanner F. C., Boehm M., Akyurek L. M., San H., Yang Z. Y., Tashiro J., Nabel G. J., Nabel E. G., Circulation, 101, 2022-2025 (2000).

42) Kumar D., Bhaskaran M., Alagappan L., Tori D., Yadav I., Konkimalla S., Magoon S., Singhal P. C., Ren. Fail., 32, 254-258 (2010). 